\title{
NEW ROMANTICISMS \\ IN WILHELMINE GERMANY
}

This essay examines and connects two related issues in the literature on the history of art of the Wilhelmine Period: the canonical shift in German romantic painting from the Nazarenes to Phillip Otto Runge and Caspar David Friedrich; and the attempt to position the work of contemporary German artists (often called new idealists) as a new romanticism. At this time, art historians like Richard Muther and Cornelius Gurlitt take on a romantic sensibility in their attempts to position contemporary German art on the international scene. With the development of new idealism in German artwriting, two new romanticisms were thus founded. Modern German art (the work of Anselm Feuerbach, Hans von Marées, Arnold Böcklin, Max Klinger, and others) was claimed within a romantic tradition. And romantic painting was conceptualized anew with the focus increasingly on Friedrich and Runge, and less on the Nazarenes.

K E Y W O R D S New Idealism, German Art Historiography, Richard Muther, Cornelius Gurlitt, Arnold Böcklin.

From the fertile manure of naturalism there sprang the blue flower of a new Romanticism.

(Richard Muther, The History of Modern Painting)

A few years ago I attended a colloquium on German romantic art entitled 'Was ist romantisch an der romantischen Kunst?' [What is romantic about the romantic art?]. ${ }^{1}$ The question struck me as one about negotiations and renegotiations with the past; what is romantic about romanticism surely depends upon who is doing the asking, when, and why. The question is subtly but critically different from a similar one that was asked seventy-five years earlier by Kurt Karl Eberlein in his book Was ist deutsch in der deutschen Kunst? [What is German in German art?]. ${ }^{2}$ Deploying in (in), as compared to an (about), Eberlein asked a question that he believed admitted only one correct answer. The essential nature of German art, Eberlein argued, lay in racial purity. His 1934 Was ist deutsch in der deutschen Kunst?, published with a swastika on the cover, was the culmination of work he had pursued in the 1920s, when he was trying to describe the nature of German romantic 
painting in terms of different artistic lineages: Peter Cornelius's Rheinfrankisch restoration, Friedrich Overbeck's southern Catholicism, and Phillip Otto Runge and Caspar David Friedrich's northern line. ${ }^{3}$ For Eberlein, it was only the northern line that was truly German: " "Romantik" nennen wir die historische, geistige Erhebung der norddeutschen Neustämme, der Pommern, Schlesier, Preußen, die ihr dichterisches Zentrum Berlin und Jena, ihr künstlerisches Zentrum Dresden hatten' ['Romantic' is what we call the historical, spiritual elevation of the new clan of northern Germany, the Pomeranians, the Silesians, the Prussians, whose poetic centres were Berlin and Jena and whose artistic centre was Dresden]. ${ }^{4}$

Eberlein's art-historical method, his Kunstgeographie, provides a strong contrast to the problems raised by the more open-ended query 'Was ist romantisch an der romantischen Kunst?' [What is romantic about romantic art?]. Such a question about romanticism suggests the possibility of multiple readings of the period and, consequently, the problems that arise from a variety of interpretations. This de-essentialising spirit is typical of postmodernism; it is a strategy common in an era of the death of metanarratives. In the 1990s, postmodernism and romanticism were frequently linked in books and anthologies on literary romanticism, with titles such as Romancing the Postmodern and Romanticism and Postmodernism. ${ }^{5}$ The simple reason for this connection is that issues associated with romanticism, like irony, subjectivity, mediation, and interdisciplinarity, are often examined in postmodern writing as well. But it should be noted that this attempt to de-essentialise romanticism is not something new to recent literary criticism. In his 1924 article 'On the Discrimination of Romanticisms', Arthur Lovejoy argued for the necessity to speak of different versions of romanticism, such as an anticlassical, naturalistic English romanticism, an artificial, self-conscious German romanticism, and a classical French romanticism. ${ }^{6}$ The more recent 'postmodern discovery of Postmodernism in Romanticism', as Edward Larrissy has put it, is less about dividing romanticism into a variety of national types. Rather it focuses more on 'how we decide what the past is and whether the interpreter's view is altering the evidence'. ${ }^{7}$ Such scepticism about historical detachment is ultimately related to a series of problems concerning subjectivity and totalizing knowledge. As Philippe Lacoue-Labarthe and Jean-Luc Nancy make clear, German romantic writers associated with the Jena circle developed 'theory itself as literature' or a 'literary Absolute', which 'aggravates and radicalizes the thinking of totality and the Subject'. In other words, 'what interests us in romanticism is that we still belong to the era it opened up. ${ }^{8}$

\section{A New Romanticism in the Wilhelmine Era}

Taking an historiographical approach to the question what is romantic about romantic art, I will focus on the second half of the Imperial era in Germany (18881918), when the nation under Wilhelm II pursued a Weltpolitik, a political course to turn Germany into a world power. Wilhelmine Germany is an important case study in the renegotiation of German romanticism for at least two reasons. First, 


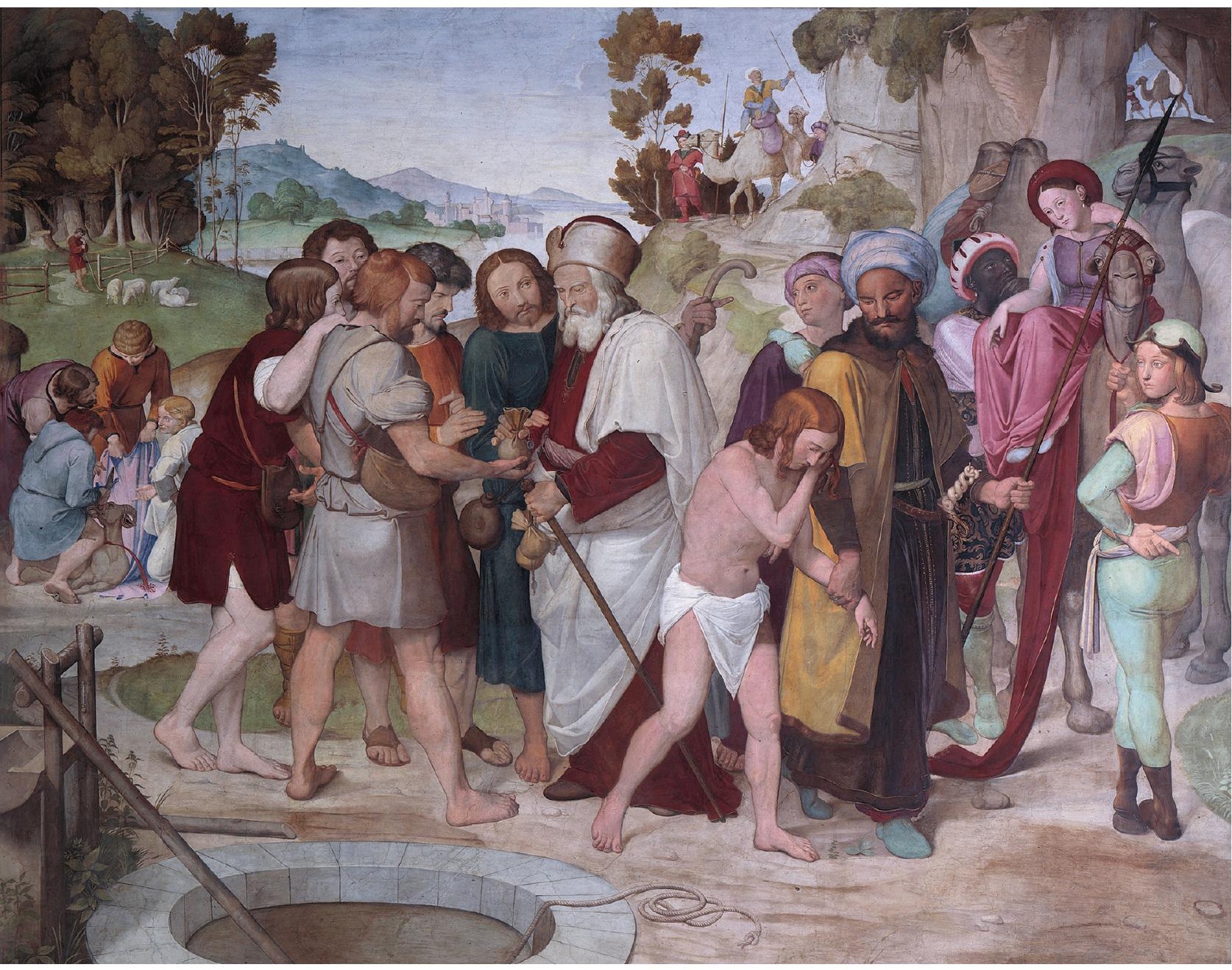

III. 1 [Friedrich Overbeck, The Selling of Joseph, 1816-1817. Fresco, 335 × 244 cm. bpk/ Nationalgalerie, Staatliche Museen zu Berlin, (previously Casa Bartholdy, Rome)/ Klaus Göken.]

an important canonical shift occurred at this time: the replacement of the Nazarenes (Friedrich Overbeck (ill. 1), Peter Cornelius and others) with Philipp Otto Runge (ill. 2), and Caspar David Friedrich (ill. 3) as the leading proponents of German romantic painting. ${ }^{9}$ Secondly, art historians like Richard Muther and Cornelius Gurlitt, who in the 1890 s wrote important surveys of modern art, used romantic terms to describe developments in contemporary German art and to situate these currents in an international context. These writers themselves show romantic sensibilities in their deep concern for the historian's subjectivity. What I would like to suggest is that these two issues are not unrelated. While the shift from the Nazarenes to Friedrich and Runge has been attributed to nationalist and modernist concerns, another important element of critical and historical 


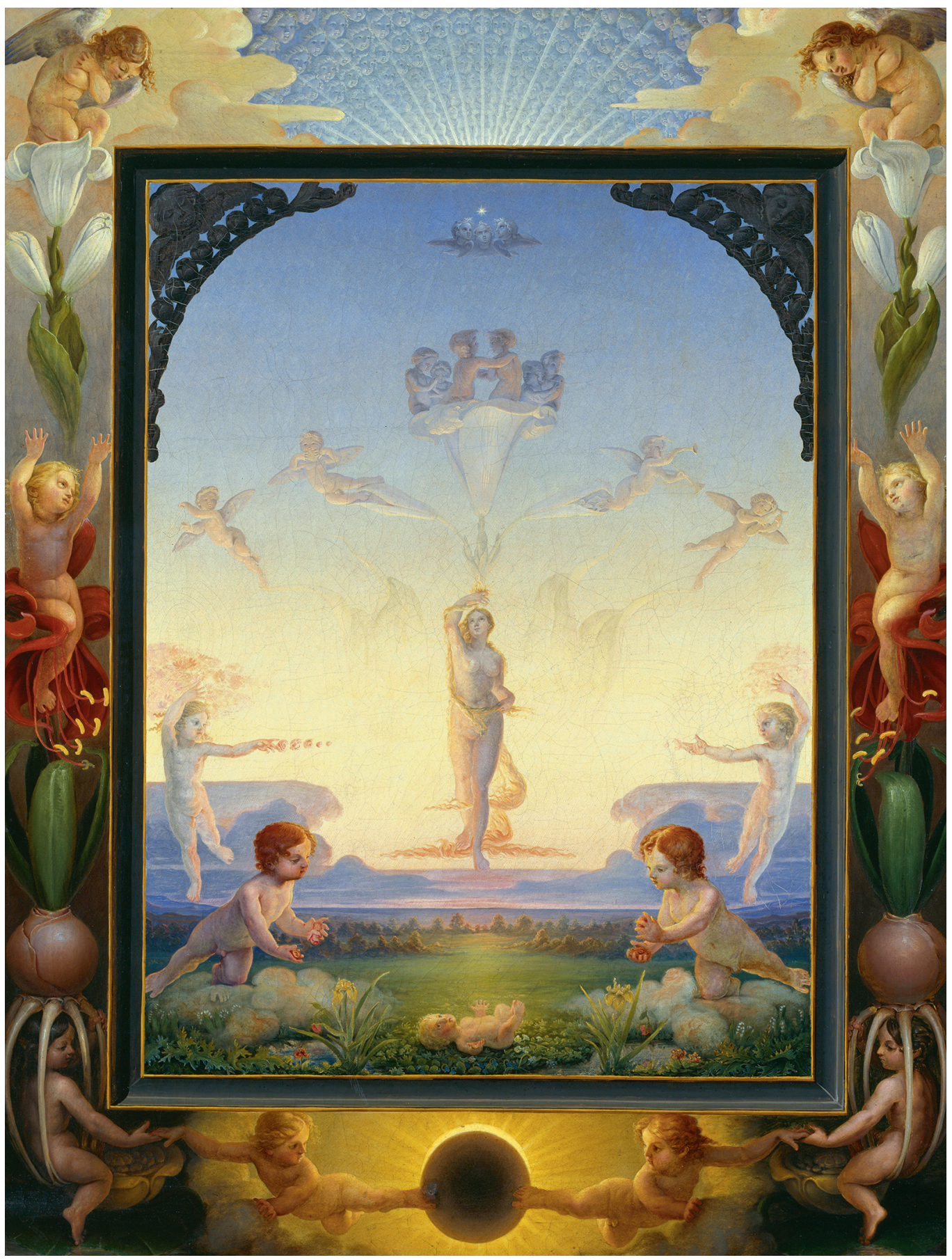

III. 2 [Philipp Otto Runge, The Small Morning, 1808. Oil on canvas, $109 \times 85.5 \mathrm{~cm}$. bpk/ Hamburger Kunsthalle/Elke Walford.] 


\section{3 [Caspar David Friedrich, Monk by the Sea, 1809-1810. Oil on canvas, $110 \times 171.5 \mathrm{~cm}$.}

bpk/Nationalgalerie, Staatliche Museen zu Berlin/Jörg P. Anders.]

writing of the time was the attempt to position, through a rhetoric of mediation, the work of late nineteenth-century German painters as a new romanticism.

In the 189os, artists such as Anselm Feuerbach, Arnold Böcklin, Hans von Marées, Adolf Hildebrand, and Max Klinger (now frequently called the DeutschRömer) were most often referred to as new idealists, a term that came from contemporary literary criticism. In his 1891 essay 'Die Krisis der Naturalismus', literature and art critic Hermann Bahr attributes the coining of the term 'Neu-Idealismus', which he describes as a 'krummen und unglücklichen Titel' [crooked and unfortunate title] to the Norwegian writer Arne Garborg..$^{10}$ In the context of contemporary German art, the term can also be found in Cornelius Gurlitt's 1893 essay on sculptor Adolf Hildebrand. In reference to the work of Hildebrand, Marées, Klinger, and Karl Stauffer-Bern, Gurlitt writes: 'Neben den Altidealisten könnte man sie Neuidealisten nennen' [Next to the old idealists, one could call them new idealists]. ${ }^{11}$ For Gurlitt, Hildebrand (ill. 4), uses his ideas and knowledge to reproduce living man, not momentary appearances. ${ }^{12}$ Gurlitt emphasizes the point that Hildebrand is fundamentally different from older idealists, like 


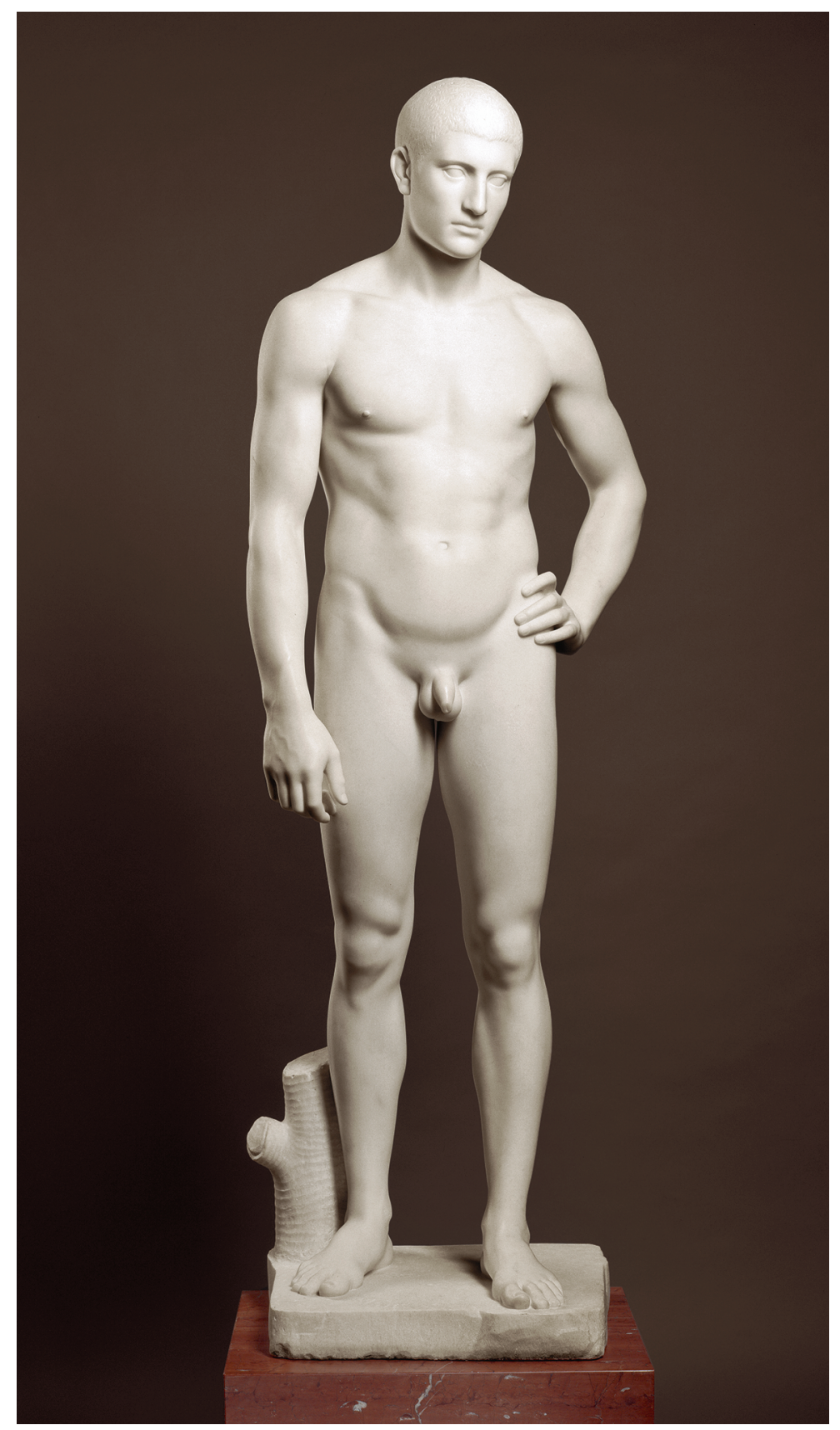

20
0
3
2
$z$
1
$\bar{\lambda}$
$\vdots$
0
$\omega$

III. 4 [Adolf von Hildebrand, Standing Young Man, 1881-1884.

Marble, $183 \mathrm{~cm}$ high. bpk/Nationalgalerie,

Staatliche Museen zu Berlin/Klaus Göken.] 


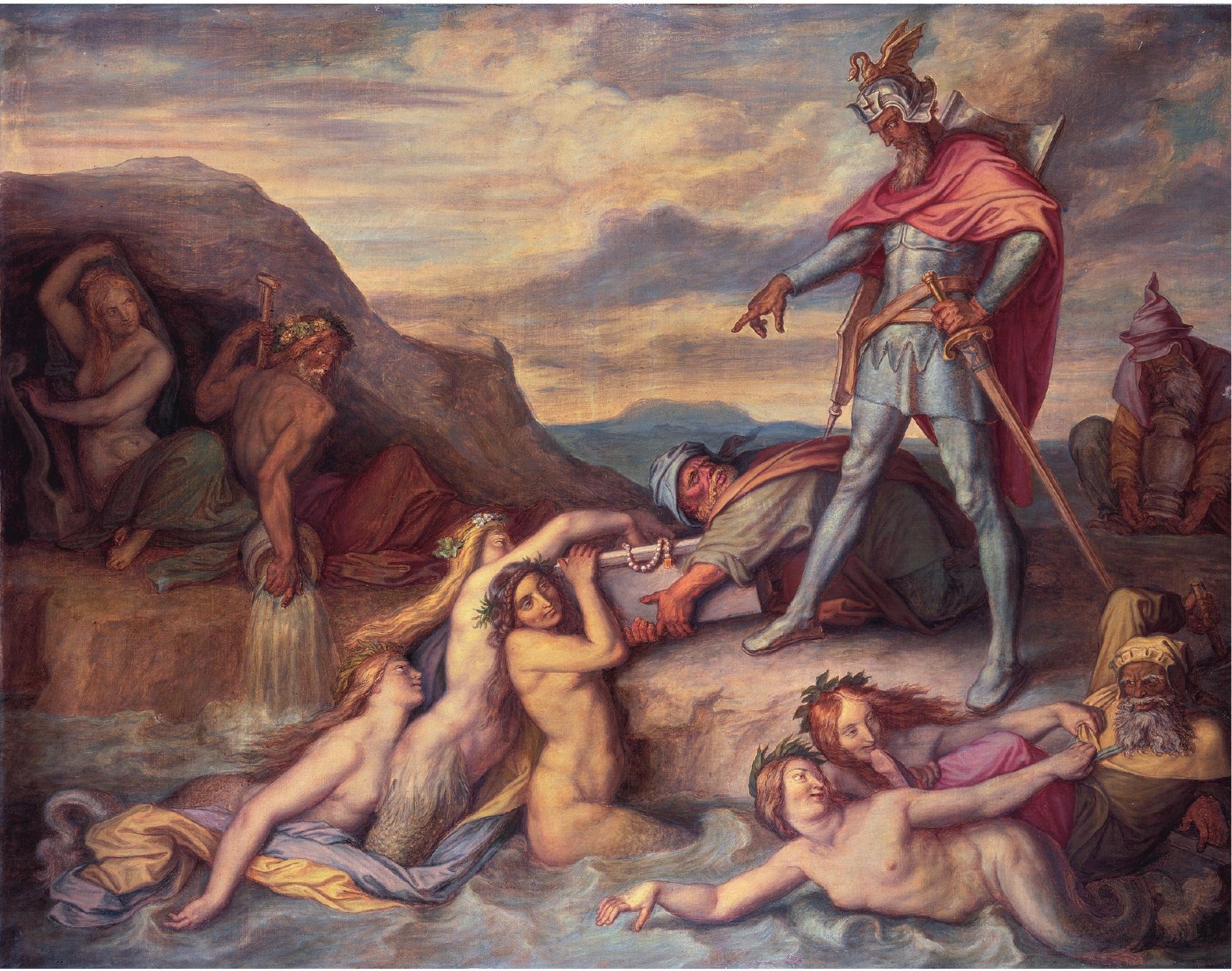

III. 5 [Peter von Cornelius, Hagen Sinks the Nibelungen Treasure, 1859. Oil on canvas, $80 \times 100 \mathrm{~cm}$. bpk/Nationalgalerie, Staatliche Museen zu Berlin/Jörg P. Anders.]

the Nazarene painter Peter Cornelius (ill. 5), who worked only in the realm of ideas. ${ }^{13}$ According to Gurlitt, Hildebrand is a 'realist', because he uses nature as his model; he is also an 'idealist', because he does not merely imitate nature, but expresses his idea (Vorstellung). ${ }^{14}$ Gurlitt reproduces this dialectic in his 1899 survey of German nineteenth-century art. He describes the work of Feuerbach, Marees, Hildebrand, Böcklin, and Klinger as integrating, in different ways, realism and idealism. ${ }^{15}$

Richard Muther also uses the term new idealism in his 1893-1894 Geschichte der Malerei im Neunzebnten Jabrbundert to describe the most recent anti-naturalistic trends in Europe, although unlike Gurlitt, Muther's perspective is more European and his model of artistic development more a 'theory of immanent exhaustion and reaction', to borrow a phrase from Meyer Schapiro. ${ }^{16} \mathrm{New}$ idealism, for 
Muther, emerged when artists were no longer satisfied with depicting 'modern life' and wanted to depict 'modern emotions'. Yet new idealism was still founded in a study of nature, which is 'the Alpha and Omega of all art'. ${ }^{17}$ Although different in orientation, Gurlitt and Muther agree in treating new idealism as a synthesis of realist and idealist tendencies. ${ }^{18}$

In the context of the re-evaluation of romanticism at this time, what is of interest is that this new German art, this new idealism, is often described also as a new romanticism. Muther begins his discussion of the German new idealists with the claim: 'From the fertile manure of Naturalism there sprang the blue flower of a new Romanticism'. ${ }^{19}$ Julius Meier-Graefe calls the Deutsch-Römer, although disparagingly, 'Neu Romantik' in his 1904 Entwicklungsgeschichte der modernen Kunst. ${ }^{20}$ And in 1921, Hans Rosenhagen, following Muther and Gurlitt's claim that a new German art developed after the rise of naturalism, suggests 'new romanticism' is a better term to describe the movement than 'new idealism.'.

The ease with which art historians at this time used 'romantic' to describe developments in modern art has to do in part with the fact that this term has, of course, both chronological and typological meanings. It could refer to a temporal period, at first defined broadly as art of the post-classical period, and later, more specifically, as art of the early nineteenth century. In fact, romanticism was in the early nineteenth century called at times Neuromantik to distinguish it from medieval romances. ${ }^{22}$ On the other hand, 'romantic' can refer to a type of poetry or art, one that is often associated with expressive, quixotic, and imaginative elements.

\section{Romanticism and New Idealism}

The connection at the turn of the twentieth century between idealism and romanticism is curious, because in the early nineteenth century idealism was more closely associated with classicism than romanticism. In fact the critical terrain has shifted with the rise of realism in the nineteenth century: realism and idealism gained the ground where romanticism and classicism once stood. ${ }^{23}$ Such binary thinking itself is, one could say, a legacy of romantic thought. A. W. Schlegel argued that oppositions like classical versus romantic and ancient versus modern were instances of the general rule that all basic forces in nature manifest themselves in polar opposites. ${ }^{24}$ As for the early nineteenth-century pairings (ancient and modern, classical and romantic, naive and sentimental), while they functioned differently for various authors, there is some general agreement that classical (or ancient or naïve) art was considered natural and cyclical, and had the possibility of perfect form, while modern (or romantic or sentimental) art was thought of as artificial, progressive, and always imperfect. The distinction is clearly made in Schiller's influential $1795^{-1796}$ 'Essay on Naive and Sentimental Poetry'. While classical man is co-extensive with nature, Schiller argues, modern man is 'in opposition with nature' in his social relations, mode of existence, and manners. Because of this opposition and a consciousness of it, the sentimental poet no longer merely imitates nature, but 'reflects on the impression the objects 
make upon him and only on the basis of that reflection is the emotion founded, into which he is transported and into which he transports us'. ${ }^{25}$ Schiller's categories are constructs that help him understand his feeling (every refined man's feeling, he says) when confronted by the simplicity of nature, whether it be the plant and animal kingdom or human nature (children, country folk, primitive races). The naive is an image of 'our lost childhood', which fills us with 'a certain melancholy', because it portrays 'our supreme perfection in an ideal sense and transports us into a state of sublime emotion'. ${ }^{26}$ There are two points I would like to emphasize here: the sentimental (modern) poet is always kept at a distance or mediated from nature; and the sentimental poet sets himself an impossible task, a longing (Sehnsucht) that cannot be fulfilled. These two concepts, mediation and longing, come to be central in defining new idealism.

I focus on Schiller's categories in the context of new idealism rather than, for example, on Friedrich Schlegel's distinction between the classical and romantic, for a variety of reasons, including the frequent association of Schiller with idealism and German national identity. As John Robertson made clear in 1905, the centenary of Schiller's death: 'To those crying for a fatherland, Schiller, with his imperturbable idealism, held out a fatherland of spirit'. ${ }^{27}$ Moreover, Schiller's ideas about childhood, simplicity, and non-mimetic or idealistic art, are often repeated in the late nineteenth and early twentieth century by authors of different aesthetic and political stripe, from Julius Langbehn's nationalist and antiSemitic diatribes in his bestseller Rembrandt als Erzieher of 1890 to the theoretical writings of Conrad Fiedler and Adolf Hildebrand. ${ }^{28}$

There were thus political as well as art historical reasons for Karl Scheffler's republication of a section of Schiller's essay on naïve and sentimental poetry in 1915 in an article 'Die Realisten und die Idealisten', which appeared just after the outbreak of the First World War in Kunst und Künstler, a progressive monthly art journal that he edited and that was closely associated with the Berlin Secession. ${ }^{29}$ Scheffler was a keen observer of artistic currents of his day. In his 1911 Deutsche Maler und Zeichner im Neunzebnten Jabrhundert, he had categorized painting according to realist and idealist poles: 'Anschauung ist das sinnliche Empfinden der Welt, ... der Begriff aber denkt über die Erscheinung und produziert die Idee' [Perception is the sensual feeling for the world, ... while conception reflects on the appearance and produces the idea]. ${ }^{30}$ The main difference between the two, between Wirklichkeitsmalerei [reality-painting] and Gedankenmalerei [thought-painting], is that 'die Anschauung malt, der Begriff zeichnet' [perception paints and conception draws]..$^{11}$ Like his mentor Julius Meier-Graefe, Scheffler categorized German art in general (although there were exceptions) as a conceptual and linear Gedankenkunst [thought-art].

Scheffler's categories were developed in a critical context in which German art was almost always seen in relation to French artistic standards. In the 1880s, French impressionism could still be rejected by art historians like Adolf Rosenberg, who claimed that 'Die Impressionisten wollen die Natur wiedergeben, nicht, wie sie ist, sondern wie sie das Auge eines einfachen, durch kein Raffine- 


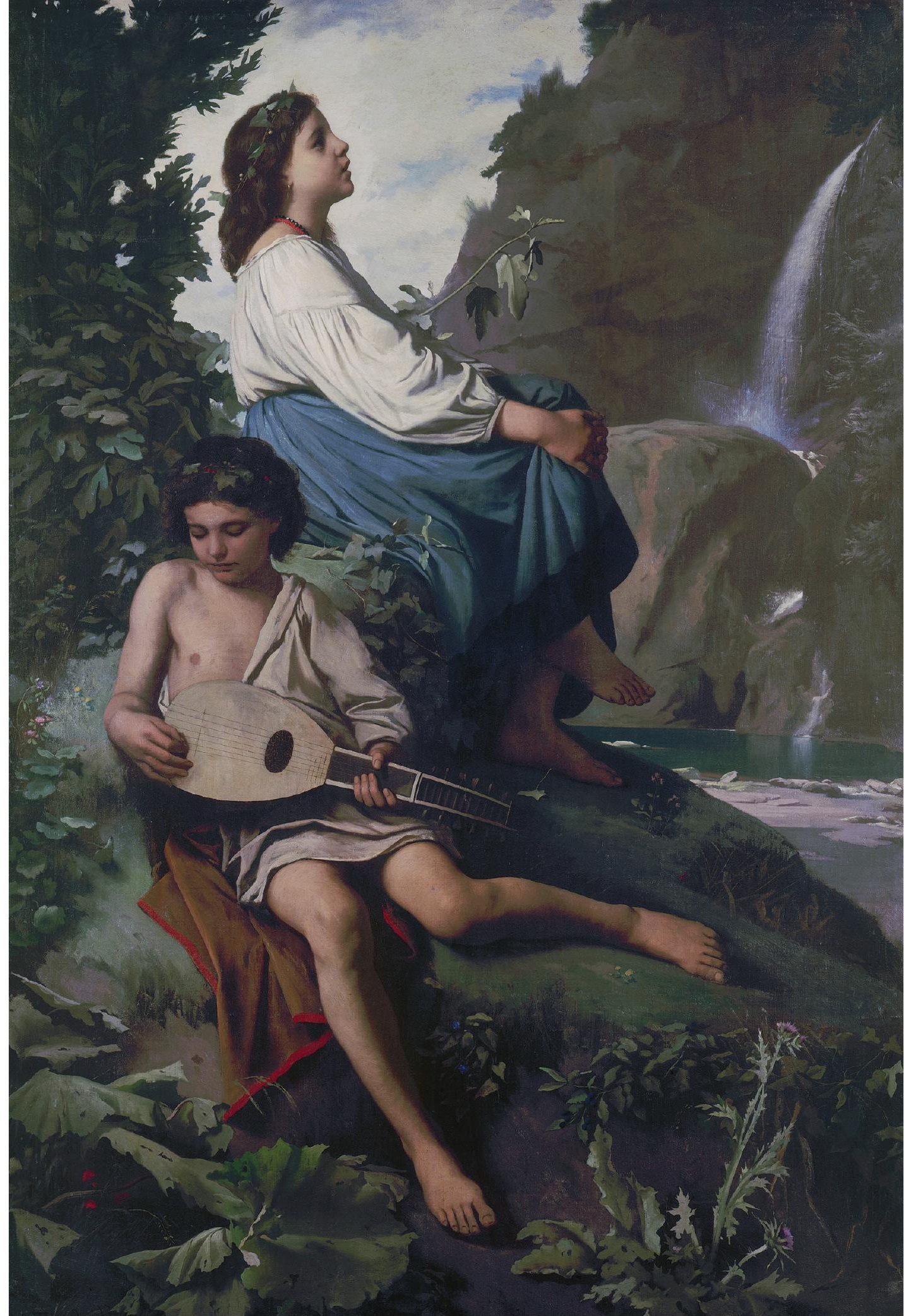

III. 6 Anselm Feuerbach, Ricordo di Tivoli, 1867. Oil on canvas, $194 \times 131 \mathrm{~cm}$. bpk/Staatliche Museen Preußischer Kulturbesitz, Nationalgalerie, Berlin/BStGS.] 
ment der Bildung beeinflussten Menschen sieht' [Impressionists do not want to reproduce nature as it is, but as it is seen by the eye of a simple man without any influence of refined education]..$^{2}$ But such a position was no longer tenable in the 1890s, when most German art critics and historians regarded French realism and impressionism as essential currents in modern art. While artists like Adolf Menzel and Max Liebermann were seen in the light of these trends, German art in general continued to be classified as idealist and imaginative, as Scheffler and Meier-Graefe make clear. In fact, it became a commonplace in German artwriting of this time to contrast the immediacy of French painting (whether it be in terms of the object in realism or the sense-perception in impressionism) with the distant and mediated art of Germany. ${ }^{33}$ As early as 1887, Emil Heilbut (writing under his pseudonym Herman Helferich) described French landscape painting as objective, scholastic, and unimaginative in comparison to the modern, skilful (kunstvoll), and ideal art of Arnold Böcklin. ${ }^{34}$

I have been arguing that in the second half of the Imperial period, the critical opposition in much art historical writing about modern art was realism and idealism, which replaced the earlier distinction between classicism and romanticism. These pairs, however, are similar in at least one respect. In both cases, an art of immediacy (classicism or realism) is opposed to a mediated art form (romanticism or idealism). It is, perhaps, for this reason that new idealism could be so easily described as a new romanticism. Schiller's essay, as discussed above, focused on mediating factors in sentimental art. This notion of mediation or 'romantic distance', as Hans Eichner points out, 'soon became a cliché'.35 For example, in Clemens Brentano's Godwi (1801), Maria defines romanticism in the following terms: 'Everything which stands between our eye and an object to be seen at a distance, making it seem closer to us, but at the same time adding to the object something of its own, is romantic'. Godwi then replies: 'The romantic is therefore a telescope, or rather the colour of the lens and the effect the form of the lens has on the object'. ${ }^{36}$

In the 1890 , new idealism was similarly labelled as an art of mediation or distance. Richard Muther describes new idealism through a Schillerian lens as sentimental painting. 'The austerity of the antique spirit', he writes of new idealist art, and Anselm Feuerbach (ill. 6) in particular, 'is tempered by the melancholy of the modern intellect'. Olympus is filled 'with the light, the mist, the colour and the melancholy of a later and more neurotic age, the modes of which are more rich in nuances -- an age which is sadder and more disturbed by human problems than was ancient Greece'. ${ }^{37}$ In repeating Schiller's claims about the sick and melancholic character of the modern age, Muther recalls a series of oppositions, such as healthy/sick and closeness/distance, that go back to the first half of the nineteenth century.

The reception of the Swiss painter Arnold Böcklin (ill. 7), who was taken in the 1890 os by many German critics and historians as the greatest living painter, is an interesting case in point. On the one hand, he is characterized as the paradigm of the naive artist. Meier-Graefe writes of his physical, not intellectual strength. ${ }^{38}$ 


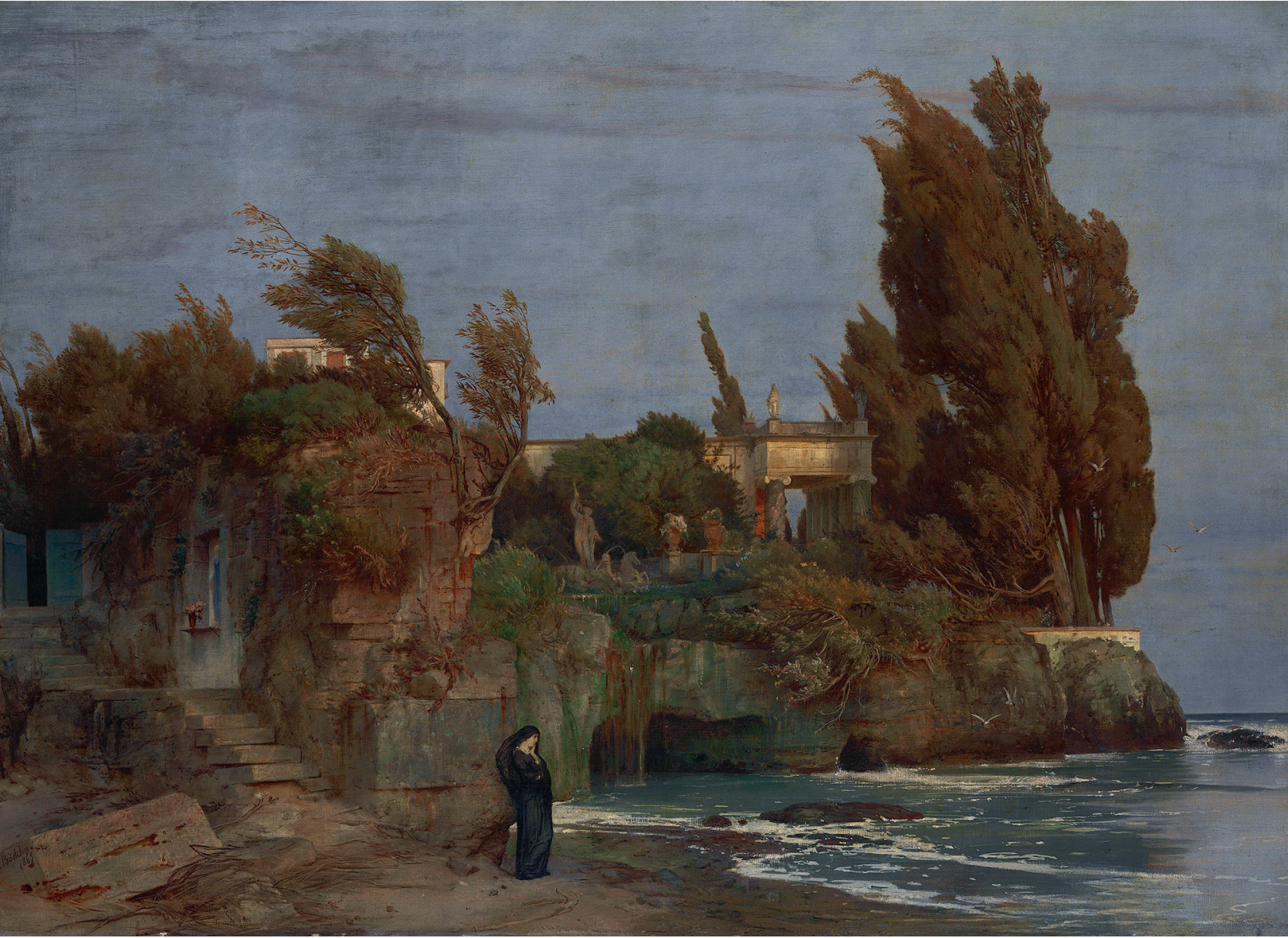

III. 7 [Arnold Böcklin, Villa by the Sea II, 1865. Oil on canvas, $123.4 \times 173.2 \mathrm{~cm}$. bpk/Bayerische Staatsgemäldesammlungen, Schack-Galerie, München/BStGS.

Gustav Floerke speaks of his powerful nearness to nature. ${ }^{39}$ Muther writes that he possesses 'iron health' and 'is as inexhaustible as infinite nature herself'. ${ }^{\circ} \mathrm{On}$ the other hand, his work is also described as mediated by his imagination and, as importantly, his powerful memory. Böcklin never sketched directly from nature, we are frequently told:

Mit Erstaunen hörte man, daß er-trotz der außerordentlichen Wahrheit mancher Details jenes Bildes, wie der mit so ungewöhnlicher Feinheit wiedergegebenen Sonnenblitze-nie unmittelbar nach der Natur male.

[With astonishment one hears that-despite the extraordinary truth of many details of every picture, like the sunlight, which he reproduces with such unusual fineness-he never painted directly from nature. $]^{41}$ 
Rather, he relied on his 'außerordentliches malerisches Gedächtniß' [extraordinary painterly memory] to recall all that he perceived to create imaginative works in his studio. ${ }^{42}$ With all new idealist artists, different forms of mediation are emphasized: Feuerbach's melancholic temperament, Klinger's imagination (ill. 8), and Marées and Hildebrand's idealism.

\section{A German Art of the Imagination}

The mediation between artist and nature comes out most succinctly in the description of the new idealists as imaginative artists. In German artwriting at this time, 'Phantasie' is used in a variety of ways: sometimes in reference to the genius of the artist; other times in the context of its role in the process of perception and in creating 'Vorstellungen' [mental images]; and other times in reference to German intellectual ability in comparison with French sensuality. In all these contexts, 'Phantasie' is almost always related to perception and memory. In fact, in popular encyclopaedias of the day, an important distinction is often made between, on the one hand, 'die reproduzierende Einbildungskraft' [the reproductive imagination], or memory, which renews 'schon dagewesene sinnlich anschauliche Vorstellungen' [already concrete sensed perceptions], and, on the other, 'die schöpferische Enbildungskraft' [creative imagination], which builds new ones. But these new images are never divorced from sense perception. Imagination:

schafft eine neue Welt, wobei sie zwar die Elemente der erstern [die wirkliche Welt], die durch die ursprünglich empfangenen Eindrücke gegebenen Vorstellungen, als Bausteine verwertet, aber durch neue und originale Verbindungen derselben neue, originale Vorstellungsgebilde hervorbringt

[creates a new world, whereby it makes use of elements of the [given world] through ideas originally received as impressions, as building blocks, but through new and original associations brings forth new, original imaginary pictures].43

This understanding of imagination as expressive could help a writer distinguish a work of art from mere imitation and, at the same time, keep it connected to sense perception. We see this employment of imagination in the construction of new idealism as a synthesis of realism and idealism.

At this time, when new idealism is being constructed as an art historical category, Runge and Friedrich begin to be viewed in terms related to this movement. While Cornelius, Overbeck, and other Nazarenes are marginalized as old idealists, the work of Friedrich and Runge is described, like that of the new idealists, as synthesizing realist and idealist trends. Scheffler explains that Runge and Friedrich cannot be categorized in terms of either 'Gedankenmalerei' [thoughtpainting] or 'Wirklichkeitsmalerei' [reality-painting], but as a mixture of the two. Runge naturalizes his perceptions at the same time as he monumentalizes feelings, while Friedrich's paintings contain both 'unmittelbar lebendige Anschau- 


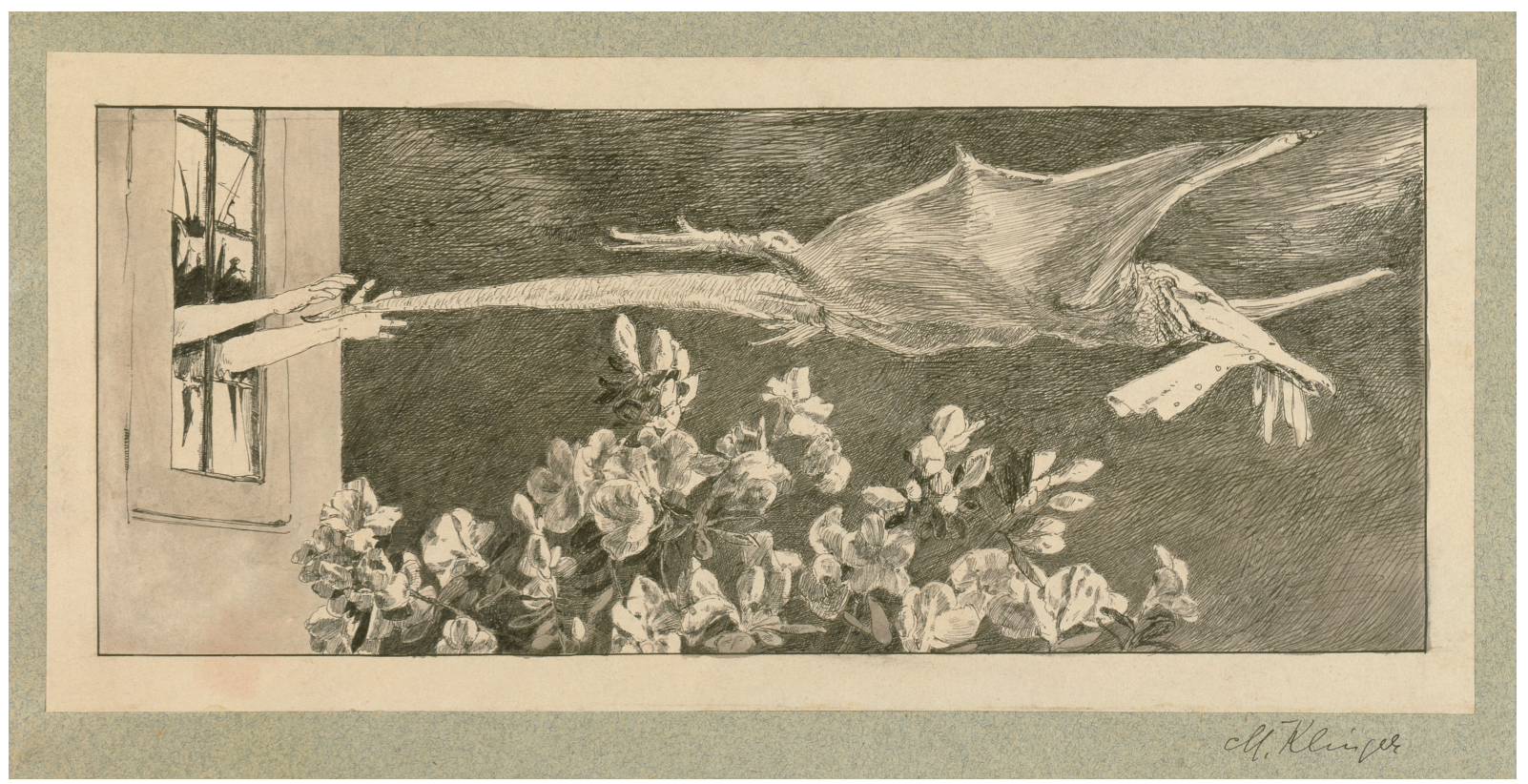

III. 8 [Max Klinger, Abduction from the series Fantasies about a Found Glove Dedicated to the Lady who Lost it, 1878. Pen and ink with wash, 9 × $22 \mathrm{~cm}$. bpk/Nationalgalerie, Staatliche Museen zu Berlin, Sammlung Scharf-Gerstenberg /Volker-H. Schneider.]

ung' [immediate, living perception] and 'dialektischer Symbolismus' [dialectical symbolism].44 Art historian Friedrich Haack, in his 1913 survey of nineteenthcentury art, similarly writes of the difficulty in categorizing Runge and Friedrich, because the former attempted 'die Nature mit eigener starker Faust zu packen und zugleich in Symbolen zu sprechen'45 [to seize nature with a strong fist and at the same time to speak in symbols], while the latter was dedicated to natural life at the same time that he 'war einer der wenigen damals, die die Stimmung einer Landschaft zu-fühlen und zu malen vermochten' [was one of the few at that time who could feel and paint the mood of a landscape $].{ }^{46}$ The attempt to bring together the artistic intention of new idealist and romantic artists is, perhaps, most clearly expressed by medievalist Josef Strzygowski in a book he published on modern art in 1907. Strzygowski argues that Runge, in his work and writings, posed the problem of landscape as the expressive vessel of human thought and aspiration, a problem whose solution Friedrich attempted and Böcklin actually achieved. ${ }^{47}$

\section{New Romantic Art Historians}

Romantic notions of distance and mediation are central concepts in the definition of new idealism. They are also important factors in how art historians, like Muther and Gurlitt, were positioning themselves in the scholarly field in com- 
parison to older art historians, like Adolf Rosenberg. In his survey of modern art written in the 188 os, Rosenberg claimed that the historian has 'die Pflicht, die Thatsachen aus dem Bereiche der subjektiven Meinungen herauszuheben und die Strömungen und Gegenströmungen zu analysiren, aus welchen sich die Folge der Thatsachen entwickelt hat' [the duty to remove the facts from the area of subjective opinions and to analyse the currents and opposing currents from which the consequences of the facts have developed $] .4^{8}$ Muther and Gurlitt rejected such an empiricist stance and, as we will see below, showed great concern for their own historical position in the context of writing about modern art and for conceptualizing German art in European-wide developments. One could call Muther and Gurlitt optimistic nationalists in the sense that they believed that German art was about to take the lead on the world stage. As with their concept of new idealism, they thus write their histories Janus-faced, looking to both the past and future. ${ }^{49}$

In his 1893-1894 Geschichte der Malerei im Neunzehnten Jabrbundert, Muther sets his goal to write the first narrative history of modern painting, as compared to earlier histories, which, he believed, were mere chronicles of painters and works. Although Muther is not a terribly theoretically minded art historian, he does see problems with his task. I write 'see', because he uses visual metaphors throughout his introduction: he speaks of the 'gaze' of the historian and of 'seeing' only the first rank of artists. Muther's primary visual problem turns out to be one of distance: 'It is a pity that we cannot see what is too near any more than what is too far away'.50 In modern times there is 'a chaos of pictures' and it is difficult 'to discover the spiritual bond which connects them all'. ${ }^{51}$

To solve this problem of nearness, Muther first makes a general claim about his approach. Following Zola's famous description of a work of art as 'a piece of nature seen through a temperament', Muther states: 'in my book I shall give no more than a piece of art-history seen through the medium of a temperament'.52 This claim to subjectivity, that is, to an art history mediated by the art historian, is then countered with a more 'objective' position..$^{53}$ He believes he can gain distance on contemporary artists by studying them 'objectively as though they were long dead masters' ${ }^{54}$ Just as we write about old artists who made new contributions, so Muther uses the criterion of novelty to determine which artists are important and to plot his evolution of modern art. Novelty is also Muther's justification for his own undertaking. His text begins: 'There is an entire series of books on modern art. A new one added to the list must needs prove its right to be called new'. ${ }^{55}$ His narrative of innovation thus structures the past by imposing order on the chaos he sees. Through distancing techniques, he believes he can turn what is close and unintelligible into what is distant, yet familiar.

In his 1899 Deutsche Kunst des neunzehnten Jabrbunderts, Cornelius Gurlitt is also concerned with self-positioning. Like earlier survey texts, he organizes his material chronologically and emphasizes the rise of landscape painting and realism. Gurlitt's book, however, is peppered with personal anecdotes, discussions of philosophical thought, and frequent use of the first-person singular. ${ }^{56}$ (Muther 
later claimed that Gurlitt's text read like an exciting novel.) $)^{57}$ This colloquial approach helps establish Gurlitt's subjective position, which he clearly enunciates in his text: 'Mein Urteil ist meines und ist nur soviel wert, als ich selbst wert bin' [My judgment is mine and is only worth as much as I myself am worth].$^{58}$ Gurlitt felt compelled to write his text by 'ein innerer Trieb' [an inner drive], as strong as that which compels an artist to paint. ${ }^{59}$ Unlike Muther, Gurlitt does not shy away from a closeness to his material: his survey, he claimed later, was a type of autobiography. ${ }^{60}$ As compared to Muther the realist, who claims that he depicts an objective world from a subjective position, Gurlitt the new idealist believes himself to be solely dependent on his own individuality and expects as much from others. If his judgments were taken as ruling, 'ich halte jeden solchen Sieg für eine Niederlage' [I would take such a victory as a defeat]. ${ }^{61}$

Muther and Gurlitt both recognize the issue of the historian's subjectivity even if they come to different conclusions about how they position themselves. Their attempts to create an art history mediated by the position of the art historian can be understood as a legacy of romanticism, at least that is how Julius Meier-Graefe thought of it when he called historians like Muther, 'Neuerungsschwärmer', a disparaging term that indicated their enthusiastic, emotional, and romantic tendencies. ${ }^{62}$ After Muther and Gurlitt attempted to secure a place in the canon for new idealism, it was demoted in Meier-Graefe's influential 1904 Entwicklungsgeschichte der modernen Kunst and in most later surveys. While MeierGraefe discusses German art, his text is concerned with the only 'essential' artistic current, the French realist tradition, which culminated in Manet, whose works do not demonstrate 'an idea, a theory', but are rather unified organisms. Such a unity is common, Meier-Graefe argues, 'to all great-that is to say, to all instinctive-epochs, when artists were unconscious of any obligation to create for the pleasure of others'. ${ }^{63}$

Muther and Gurlitt, acknowledging their subjective positions, described their scholarly activity along the lines of artistic creativity. Meier-Graefe, on the other hand, rejected such a model. He worked more like an evolutionary biologist or morphologist in describing art's formal development. His survey's title, Entwicklungsgeschichte der modernen Kunst [Evolution of modern art], suggests this analogy, as does his favourite metaphor of growth, the tree. ${ }^{64} \mathrm{New}$ idealism was omitted from this narrative of modern art, because it did not fit the formalist's notion of art as instinctive, or, in Schiller's terms, naïve. Taken as intellectual and mediated in nature, new idealism was antithetical not only to sensual French art, but also to a narrative structure based on formal considerations and progress. Because of the individuality of the artist in Germany, Meier-Graefe explains, no schools formed and tendencies arose arbitrarily. Modern German art history, according to Meier-Graefe, is thus only 'a chain of accidents'. ${ }^{65}$

While Muther and Gurlitt champion new idealism and Meier-Graefe condemns it, the terms of the debate, however, have not really changed. New idealist art is considered German in terms of its romantic, conceptual, and mediated qualities. What changes with Meier-Graefe is the value given to such an artistic 
enterprise. Art historians after Meier-Graefe who champion German art of the nineteenth century frequently do so along the same romantic lines. For example, the Munich art historian Georg Jacob Wolf, writing in 1919, uses the concept 'Deutsche Malerpoeten' to construct a narrative of German nineteenth-century painting. What links all the German painter-poets is 'Sehnsucht' [longing]: Friedrich's desire for pantheistic colour; the Nazarenes' for God; Schwind, Spitzweg, and Waldmüller's for a fairy-tale world; and Feuerbach, Böcklin, and Marées's for the Italian sun. ${ }^{66}$

\section{Two New Romanticisms}

To summarize: in the second half of the Imperial period, art historians like Muther and Gurlitt take on a romantic sensibility in promoting new idealism, sometimes called a new romanticism. At the same time, romantic artists, like Friedrich and Runge, are described in similar terms to those used for the new idealists. An important question to ask is what are the implications of the concept of the 'new' (or 'neo')? How is German romanticism of the early nineteenth century, the 'old romanticism', understood after the development of a 'new romanticism'? The most important point, it seems to me, is that the relation between the new and the old is not uni-, but bidirectional. Concepts from German romanticism played an important role in how art historians defined new idealism, and concepts from new idealism played as decisive a part in re-conceptualizing German romanticism.

In terms of the understanding of the German romantic painting at this time, I would like to highlight three issues. First, the Nazarenes tend to be labelled at the turn of the twentieth century as (old) idealists and thus grouped with the classicists (or neo-classicists, as we now call them). Muther writes that the Nazarenes and the classicists were both mere imitators:

The Classicists had imitated with a certain cold erudition; so [the Nazarenes] imitated out of the depths of their emotion. As the former used the Greeks, so they used the fourteenth-century painters, as patterns of calligraphy from which they did their copies ... ${ }^{67}$

Similar sentiments are voiced by Scheffler and others. ${ }^{68}$ That neoclassical and certain romantic artists were described as idealists suggests how much the debates have changed with the rise of realism in European painting. The Nazarenes are still considered romantics, but romantics defined in terms of an old idealist tradition.

Secondly, Runge and Friedrich, as discussed above, were viewed as creating paintings that combine natural observation and artistic feeling or imagination. This synthesis of realist and idealist tendencies was a key component in how art historians, like Muther and Gurlitt, defined new idealism. Similarly W. von Seidlitz, claimed that Böcklin 'stellte die bewundernswerthe Schärfe seines Auges in den Dienst ganz phantastischer Darstellungen aus einem Reiche von Fabel- und 
Götterwesen' [put the admirable acuteness of his eye in the service of entirely imaginative representations from the realm of fable and mythology] ${ }^{69}$ And Max Schmid emphasizes Max Klinger's training under the realist painter Carl von Gussow, but concludes that his perceptiveness and powers of observation were what allowed his imagination to thrive. ${ }^{70}$

Finally, Friedrich and Runge were often categorized in terms of their individuality just as new idealism was characterized by Gurlitt, Muther, and MeierGraefe not as a school like realism, impressionism or the Nazarenes, but as a group of artists who prized their individuality. Gurlitt, who developed his ideas on individualism from Langbehn ('Indvidualität haben, heißt Seele haben' [Having an individuality means having a soul]), entitled the chapter on new idealism in his 1899 survey of modern German art 'Die Kunst aus Eigenem' [Art of one's own $].^{71}$ Museum director Hugo von Tschudi claimed that Marées, Feuerbach, and Böcklin took almost nothing from one another. ${ }^{72}$ The individuality of Friedrich and Runge is also emphasized at this time in comparison with the group efforts of the Nazarenes. Muther claimed that Runge 'would create new art, not by the repetition of what is already in existence, but by an independent penetration into nature'. He pursued his studies of nature, Muther explains, not as part of an academy but as an individual. ${ }^{73}$ Meier-Graefe, moreover, begins his chapter on 'The Generation of 1890' in his Entwicklungsgeschichte with Runge as an example of 'great solitaries' in the history of modern German art, like the new idealists Feuerbach and Marées. ${ }^{74}$

With the development of new idealism in German artwriting, two new romanticisms were thus founded. Modern German art, the work of Feuerbach, Marées, Böcklin, Klinger, and others, was claimed within a romantic tradition, and German romantic painting was reconceptualized with a new focus on Friedrich and Runge and a waning of interest in the Nazarenes. 


\section{Notes}

1 This essay is based on a paper I delivered at the conference "Was ist romantisch an der romantischen Kunst?: Kunsttheorie und Künstlerpraxis' at the Georg-August Universität Göttingen, 2009.

2 Kurt Karl Eberlein, Was ist Deutsch in der Deutschen Kunst? (Leipzig: E. A. Seemann, 1934).

3 Kurt Karl Eberlein, 'Kunst und Kunstgeist der Nazarener', in Die Malerei der deutschen Romantiker und Nazarener im besonderen Overbecks und seines Kreises, ed. Carl Georg Heise (Munich: Kurt Wolff, 1928), 21.

4 Kurt Karl Eberlein, Deutsche Maler der Romantik (Jena: Eugen Diederich, 1920), 122. All translations unless otherwise indicated are my own.

5 Diane Elam, Romancing the Postmodern (London: Routledge, 1992); Edward Larrissy, ed., Romanticism and Postmodernism (Cambridge: Cambridge University Press, 1999). See also Stephan Copley and John Whale, eds., Beyond Romanticism: New Approaches to Texts and Contexts, 1780-1832 (London: Routledge, 1992); John Beer, ed., Questioning Romanticism (Baltimore: The John Hopkins University Press, 1995).

6 Arthur Lovejoy, 'On the Discrimination of Romanticisms', PMLA 39, no. 2 (1924): 236-7.

7 Edward Larissy, 'Introduction', in Larissy, Romanticism and Postmodernism, 1.

8 Philippe Lacoue-Labarthe and Jean-Luc Nancy, The Literary Absolute: The Theory of Literature in German Romanticism, trans. Philip Barnard and Cheryl Lester (Albany: State University of New York Press, 1988), 12, 15.

9 Although Runge and Friedrich's paintings began to draw critical attention in the 1890 os, it was the 1906 Deutsche Jabrhundertausstellung in Berlin that was a decisive moment of change in the reassessment of German romanticism. For some recent discussions of these issues, see Sabine Beneke, Im Blick der Moderne: Die 'Jahrbundertausstellung deutscher Kunst (1775-1875)' in der Berliner Nationalgalerie 1906 (Berlin: Bostelmann \& Siebenhaar, 1999); Mitchell B. Frank, German Romantic Painting Redefined: Nazarene Tradition and the Narratives of Romanticism (Aldershot: Ashgate, 2001), and Christian Scholl, Revisionen der Romantik: Zur Rezeption der 'neudeutschen Malerei' 1817-1906, with the assistance of Kerstin Schwedes and Reinhard Spiekermann (Berlin: Akademie Verlag, 2012). Scholl's impressive study includes a thorough bibliography (original sources and secondary literature) on the subject of revisions of romanticism in the nineteenth century.

10 Hermann Bahr, 'Die Krisis des Naturalismus', in Hermann Bahr, Kritische Schriften in Einzelausgaben, ed. Claus Pias, vol. 2, Die Überwindung des Naturalismus (Weimar: VDG, 2004), 61.

11 Cornelius Gurlitt, 'Adolf Hildebrand', Die Kunst unserer Zeit 4, no. 2 (1893): 76.

12 Ibid., 71.

13 The association of the Nazarenes with idealists began in the mid-nineteenth century. See Mitchell B. Frank, 'Ingres and the Nazarenes', in Fictions of Isolation: Artistic and Intellectual Exchange in Rome during the First Half of the Nineteenth Century, ed. Lorenz Enderlein und Nino Zchomelidse (Rome: Brettschneider, 2006), 67-78.

14 Gurlitt, 'Adolf Hildebrand', 71.

15 Cornelius Gurlitt, Deutsche Kunst des neunzehnten Jabrhunderts, 2nd ed. (Berlin: Georg Bondi, 1900), 596-656.

16 Meyer Schapiro, 'On the Nature of Abstract Art', in Modern Art: 19th and 2oth Centuries (New York: George Braziller, 1978), 188. 
Richard Muther, The History of Modern Painting, trans. Ernest Dowson et al., vol. 3 (London: Henry and Co., 1895), 551. For the original German text, see Richard Muther, Geschichte der Malerei im Neunzebnten Jabrhundert, vol. 3 (Munich: G. Hirth, 1893-94), 453.

18 It should be noted that in the 1890 , realism is at times distinguished from naturalism. The former is often considered an ahistorical stylistic category while the latter is considered a nineteenth-century phenomenon associated with Nietzsche, Balzac, and Zola. Philologist Christian Muff, for example, writes: 'Idealismus und Naturalismus können sich so wenig vertragen wie Feuer und Wasser. Wohl aber vertragen sich Idealismus und Realismus sehr gut, ja wir müssen sagen, sie hängen so eng zusammen, daß sie einer des anderen nicht entbehren können'. ['Idealism and naturalism get along together as badly as fire and water. But idealism and realism get along very well together; we can even say they are so closely connected that one cannot manage without the other'.] See Christian Muff, Idealismus, 2nd ed. (Halle: Richard Mühlmann, 1892), 32.

19 Muther, The History of Modern Painting, 3:741. (Muther, Geschichte der Malerei im Neunzebnten Jahrbundert, 3:603).

20 Julius Meier-Graefe, Modern Art, trans. Florence Simmonds and George Chrystal, vol. 2 (London: William Heinemann, 1908), 311. For the original German text, see Julius Meier-Graefe, Entwicklungsgeschichte der modernen Kunst, vol. 2 (Stuttgart: Hoffmann,1904), 704.

21 Adolf Rosenberg, Handbuch der Kunstgeschichte, 4th ed. (Bielefeld and Leipzig: Velhagen \& Klasing, 1921), 576. Also see Emil Heilbut 'Die neuen Erwerbungen der Nationalgalerie', Kunst und Künstler no. 3 (1905): 32, for a description of Arnold Böcklin's work as achieving a classicizing romanticism.

22 Hans Eichner, 'Germany / Romantisch-Romatik-Romantiker', in 'Romantic' and its Cognates / The European History of a Word, ed. Hans Eichner (Toronto: University of Toronto Press, 1972), 149.

23 Adolf Rosenberg observed that the realists of the 184 os were in the 188 os considered Idealists. See Rosenberg, Geschichte der modernen Kunst, vol. 1 (Leipzig: Fr. Wilh. Grunow, 1884-I889), 293.

24 See Eichner, 'Germany / Romantisch-Romatik-Romantiker', 136.

25 Friedrich Schiller, 'On Naive and Sentimental Poetry', in Friedrich Schiller, Essays, ed. Walter Hinderer and Daniel Dahlstrom (New York: Continuum, 1993), 204.

26 Ibid.,181.

27 John Robertson, Schiller: After a Century (Edinburgh: W. Blackwood and sons, 1905), 15. On Schiller's reception at this time, see also Hans Mayer, 'Schillers Nachruhm', Études Germaniques 14 (1959): 374-85; and Nicholas Martin, 'Introduction: Schiller After Two Centuries', in Schiller: National Poet-Poet of Nations: A Birmingham Symposium, ed. Nicholas Martin (Amsterdam: Rodopi, 2006), 7-21.

28 Julius Langbehn, Rembrandt als Erzieher, 45th ed. (Leipzig: C. L. Hirschfeld, 1900), 245-7; Konrad Fiedler, Beurteilung von Werken der bildenden Kunst, in Schriften zur Kunst, ed. Gottfried Boehm, vol. 1 (Munich: Fink, 1991), 33; Fiedler, On Judging Works of Visual Art, trans. Henry Schaefer-Simmern and Fulmer Mood (Berkeley: University of California Press, 1949), 49-50; Adolf Hildebrand, Das Problem der Form in den bildenden Kunst, 14th ed. (Strassbourg: Heitz, 1918), 114-5; Adolf Hildebrand, The Problem of Form in the Fine Arts, in Empathy, Form and Space: Problems in German Aesthetics, 1873-1893, trans. and eds. Harry Francis Mallgrave and Eleftherios Ikonomou (Santa Monica, CA: Getty Center, 1994), 269.

29 Karl Scheffler, 'Die Realisten und die Idealisten', Kunst und Künstler 13 (1915): 291-306. 
Karl Scheffler, Deutsche Maler und Zeichner im Neunzebnten Jabrbundert (Leipzig: Insel, 1911), 3.

Rosenberg, Geschichte der modernen Kunst, 1:338. In the 1880s, French impressionism tended to be ridiculed in Germany by critics who chastised it for rejecting artistic principles of ideal beauty and omitting non-essential elements. See Beth Irwin Lewis, Art For All?: The Collision of Modern Art and the Public in Late-Nineteenth-Century Germany (Princeton: Princeton University Press, 2003), 61.

33 As Jay Clark has demonstrated, new idealism specifically was promoted as 'a native alternative to French Impressionism and Symbolism'. See Jay A. Clark, 'Neo-Idealism, Expressionism, and the Writing of Art History', in Negotiating History: German Art and the Past, ed. Jay A. Clark, special issue of Museum Studies 28, no. 1 (2002): 26.

34 Herman Helferich (Emil Heilbut), Neue Kunst (Berlin: Lehmann, 1887), 68.

35 Eichner, 'Germany / Romantisch-Romantik-Romantiker', 125.

36 As quoted in ibid. Brad Prager argues that the fundamental questions raised by Brentano's novel, in which 'fragmented, Romantic subjectivity is illustrated by way of references to visual perception through a glass or a lens', concern 'mediation'. See Prager, Aesthetic Vision and German Romanticism (Rochester: Camden House, 2007), 78.

37 Muther, The History of Modern Painting, 3:558. (Muther, Geschichte der Malerei im Neunzebnten Jabrbundert, 3:459). This quotation is from a description of new idealist painting in general, but Muther uses the same idea, almost word for word, in his discussion of Feuerbach. See Muther, The History of Modern Painting, 3:472. (Muther, Geschichte der Malerei im Neunzehnten Jabrhundert, 3:409).

38 Meier-Graefe, Modern Art, 2:132. (Meier-Graefe, Entwicklungsgeschichte der modernen Kunst, 2:449).

40 Muther, The History of Modern Painting, 3:760, 744. (Muther, Geschichte der Malerei im Neunzebnten Jahrhundert, 3:620, 606).

41 Friedrich Pecht, Deutsche Künstler des neunzehnten Jabrhunderts: Studien und Erinnerungen, vol. 2 (Nördlingen: C. H. Beck’schen Buchhandlung, 1887) 196.

42 Ibid. For discussions of Böcklin's extraordinary memory, see also Floerke, Zebn Jahre mit Böcklin, 42; Gurlitt, Deutsche Kunst des neunzehnten Jabrbunderts, 623; and Fritz von Ostini, Böcklin (Bielefeld: Velhagen \& Klasing, 1905), 29.

43 'Phantasie', in Meyers Konversations-Lexikon, vol. 12 (Leipzig and Vienna, 1885-1892), 984. The division of Phantasie into two modes (reproductive and creative) in the encyclopedia literature goes back at least to 1817 . See 'Phantasie', Conversations-Lexicon oder encyclopädisches Handwörterbuch für gebildete Stande (Stuttgart, 1817), 478-82. The distinction between reproductive and creative imagination was made in the early eighteenth century by Christian Wolff (1679-1754). See James Engell, The Creative Imagination: Enlightenment to Romanticism (Cambridge, MA: Harvard University Press, 1981), 95 .

44 Scheffler, Deutsche Maler und Zeichner, 37-8, 41-2.

45 Friedrich Haack, Die Kunst des XIX. Jahrbunderts, 4th ed. (Esslingen a. N.: Paul Neff Verlag 1913), 202.

46 Ibid., 205 .

47 Josef Strzygowski, Die bildende Kunst der Gegenwart: Ein Büchlein für jedermann, (Leipzig: Quelle \& Meyer, 1907), 220-1. 
Rosenberg, Geschichte der modernen Kunst, 2:7.

49 For some recent discussions of German art survey texts at this time, see Beneke, Im Blick der Moderne, 16-29; and Scholl, Revisionen der Romantik, 475-519.

50 Muther, The History of Modern Painting, 1:2. (Muther, Geschichte der Malerei im Neunzebnten Jahrbundert, 1:2).

51 Muther, The History of Modern Painting, 1:3. (Muther, Geschichte der Malerei im Neunzebnten Jahrbundert, 1:3).

52 Muther, The History of Modern Painting, 1:2. (Muther, Geschichte der Malerei im Neunzebnten Jabrbundert, 1:2).

53 Muther's subjective stance was noticed during his time. See H. A. Lier's review of Muther's Geschichte der Malerei im Neunzehnten Jabrbundert in Zeitschrift für bildende Kunst 5 [neue Folge] (1894): 219-23. For more recent discussions of Muther's work, see Rotraud Schleinitz, Richard Muther: Ein provokativer Kunstschriftseller zur Zeit der Münchener Secession. Die "Geschichte der Malerei im XIX. Jahrhundert”: Kunstgeschichte oder Kampfgeschichte? (Hildesheims: Georg Olms, 1993), 150-2; and Scholl, Revisionen der Romantik, 475-519.

54 Muther, The History of Modern Painting, 1:7. (Muther, Geschichte der Malerei im Neunzehnten Jahrbundert, 1:6)

55 Muther, The History of Modern Painting, 1:1. (Muther, Geschichte der Malerei im Neunzebnten Jahrbundert, 1:1). For a discussion of the issue of novelty in Muther's work, see Schleinitz, Richard Muther, $155^{-6 .}$

56 Gurlitt had personal connections with artists and intellectuals in part due to his well-connected family: his father Louis was a well-known painter and his brother Fritz was a successful Berlin art dealer. See Jürgen Paul, Cornelius Gurlitt: Ein Leben für Architektur, Kunstgeschichte, Denkmalpflege und Städtebau (Dresden: Hellerau, 2003).

57 Muther, 'Gurlitt und ich', in Aufsätze über bildende Kunst, ed. Hans Rosenhagen, vol. 3 (Berlin: Ladyschnikow, 1914), 44.

58 Gurlitt, Deutsche Kunst des neunzehnten Jahrbunderts, 496. On Gurlitt's subjectivity, see Paul, Cornelius Gurlitt, 89; and Scholl, Revisionen der Romantik, 477.

59 Ibid.

60 As quoted in Paul, Cornelius Gurlitt, 86.

61 Gurlitt, Deutsche Kunst des neunzehnten Jabrhunderts, 497

62 See Kenworth Moffett, Meier-Graefe as Art Critic (Munich: Prestel, 1973), 48.

63 Meier-Graefe, Modern Art, 1:257-8. (Meier-Graefe, Entwicklungsgeschichte der modernen Kunst, 1:148).

64 See, for example, Meier-Graefe, Modern Art, 1:28. (Meier-Graefe, Entwicklungsgeschichte der modernen Kunst, 1:51). For the use of the tree metaphor in Meier-Graefe's writing, see Mitchell B. Frank, 'Recapitulation and Evolution in German Artwriting', in German Art History and Scientific Though: Beyond Formalism, ed. Mitchell B. Frank and Daniel Adler (Farnham: Ashgate, 2012), 107-9.

65 Meier-Graefe, Modern Art, 2:311. (Meier-Graefe, Entwicklungsgeschichte der modernen Kunst, 2:704).

66 Georg Jacob Wolf, Deutsche Malerpoeten (Munich: F. Bruckmann, n. d. [1919]), 3.

67 Muther, The History of Modern Painting, 1:225. (Muther, Geschichte der Malerei im Neunzehnten Jahrbundert, 1:196).

68 Scheffler, Deutsche Maler und Zeichner, 10; Max Osborn, Die Kunst von 1800 bis zur Gegenwart, 8th ed. (Leipzig: Seemann, 1921), 27; T. de Wyzewa, Les Chefs-d'oeuvre de l'art au XIXe Siècle, vol. 4, La 
Peinture étrangère (Paris: Librairie Illustrée, n. d. [1901]), 14; Max Schmid, Kunstgeschichte des XI Jahrhunderts, vol. 2 (Leipzig: Seemann, 1904), 1.

69 Woldemar von Seidlitz, Die Entwickelung der modernen Malerei (Hamburg: J. F. Richter, 1897), 18.

70 Max Schmid, Klinger (Bielefeld and Leipzig: Velhagen und Klasing, 1906), $7 \mathrm{ff}$. Gurlitt (Deutsche Kunst des neunzebnten Jabrhunderts, 634) had similarly described Klinger's art in terms of realism and idealism, concluding: 'Aus einem Nachbildner der Menschen konnte er ein Schöpfer einer ihm eigenen Menschenwelt werden, aus einem Berichterstatter ein Dichter'. ('From a copier of men he was able to become a creator of his own world of men; from a reporter, [he became] a poet').

71 Langbehn, Rembrandt als Erzieher, 11. Gurlitt, after praising Langbehn's book, similarly writes: Eine Individualität haben, heißt Seele haben; eine geschlossene Individualität haben, heißt Stil haben'. ['Having an individuality means having soul; having a complete individuality means having style'.] See Gurlitt, Deutsche Kunst des neunzebnten Jabrhunderts, 504-5, 596.

72 Hugo von Tschudi, Die deutsche Jabrhundertausstellung Berlin 1906 (Munich: F. Bruckmann, 1906).

73 Muther, The History of Modern Painting, 2:9. (Muther, Geschichte der Malerei im Neunzehnten Jabrhundert, 2:8).

74 Meier-Graefe, Modern Art, 2:311. (Meier-Graefe, Entwicklungsgeschichte, 2:703). 